International Journal of Chemical and Process Engineering Research

2014 Vol. 1, No. 4, pp. 32-42

$\operatorname{ISSN}(e): 2313-0776$

$\operatorname{ISSN}(p): 2313-2558$

DOI: $10.18488 /$ journal.65/2014.1.4/65.4.32.42

(C) 2014. Conscientia Beam. All Rights Reserved.

\title{
RESPONSE SURFACE METHODOLOGY (RSM) A GOOD OPTIMIZER FOR TRANSESTERIFICATION REACTION OF CHRYSOPHYLLUM ALBIDIUM SEED OIL TO CHRYSOPHYLLUM ALBIDIUM OIL BIODIESEL
}

\section{T. F. Adepoju ${ }^{1}$}

${ }^{1}$ Chemical Engineering Department, Landmark University, Omu-aran, Kwara State, Nigeria

\begin{abstract}
In an effort to optimize the reaction conditions of biodiesel production from Chrysophyllum albidium seed oil, Response Surface Methodology (RSM) was applied and the effects of reaction temperature $\left(X_{1}\right)$, catalyst amount $\left(X_{2}\right)$, reaction time $\left(X_{s}\right)$ and methanol/oil molar ratio $\left(X_{*}\right)$, and their reciprocal interactions were examined. A total of 30 experimental runs were generated based on Central Composite Design (CCD) and carried out. A quadratic polynomial was obtained for predicting the transesterification process and the ANOVA test showed the model to be significant $(p<0.05)$. The validity of the predicted yield $(82.7323 \%$ $w / w)$ was confirmed by carrying out three independent replicates experiments at the following optimized conditions, $X_{i}=41.63{ }^{\circ} \mathrm{C}, X_{2}=0.59$ (wt \%), $X_{s}=62.32 \mathrm{~min}$ and $X_{t}=3.00$. The optimal biodiesel yield was validated to be $82.6702 \%$ (w/w), which was well within the range predicted by the model. The fuel properties of Chrysophyllum albidium biodiesel produced were found to be within the ASTM D6751 and DIN EN 14214 biodiesel standards. The fatty acid profile of the biodiesel revealed that the dominant fatty acids were oleic (60.101\%), arachidic (2.0145\%), palmitic (18.403\%) and linoleic (18.942\%).
\end{abstract}

Keywords: Chrysophyllum albidium seed oil, Biodiesel, Trans esterification, Optimization, Response surface methodology.

\section{Contribution/ Originality}

This study contributes in the existing literature to knowledge. This study uses new estimation methodology for conversion of seed oil to biodiesel. This study originates new formula to improve the yield of biodiesel. This study is one of very few studies which have investigated the use of biomass waste to produced biodiesel. The paper contributes the first logical analysis in optimization of transesterification process. The paper's primary contribution is finding that a 
renewable energy can be obtained from biomass waste. This study documents economic impact of using biomass waste to produce biodiesel.

\section{INTRODUCTION}

The increasing in energy demand around the globe, the depletion of fossil fuels, and the fluctuation of crude oil price in the international market as well as the greater recognition of the unfavorable environmental consequences of fossil fuels has made renewable biofuels an attractive alternative to conventional fuels. Fatty acid methyl esters known as biodiesel which is considered as a substitute of convectional diesel is gaining ground as a biodegradable, environmental friendly, readily available, energy conservation and management [1]. Biodiesel is produced through a chemical process known as "transesterification or alcoholysis" in which there is displacement of alcohol from an ester under acidic or basic catalytic conditions producing free glycerol and fatty acid esters of the respective alcohol [2]. Other process includes hydrotreatment and oleaginous microorganisms [3].

Biodiesel is derived from renewable feedstock like vegetable oils or animal fats. Both edible and non-edible oils have been successfully employed in biodiesel production [4]. In developing nation like Nigeria, crude oil is used mainly to produce conventional diesel. However, there are alternative oil producing crops which can be utilized as feedstocks, such as Moringa oil, Palm oil Sorrel seed oil, Coconut oil, Beniseed oil, Sunflower oil, Melon seed oil, Jatropha oil and Groundnut oil. Chrysophyllum albidium seed oil, a new competitor is emerging as a promising feedstock.The Chrysophyllum albidium seed oil is rich in both linoleic (36.0\%) and oleic (37.6\%) fatty acids [5]. Ugboge and Akukwe [6] reported that there is a potential to use oils from nonutilized oil seeds in management of wounds. Numerous methods exist in oil separation from oilseeds such as mechanical pressing, pressurized solvent extraction, Soxhlet extraction, and ultra-sonic extraction, Aqueous Enzymatic Oil Extraction (AEOE), among others. However, in commercial sense, this oil is not in current widespread use hereby having relatively few competing medicinal and food uses.

Response surface methodology (RSM) is a useful optimization tool, which has been applied in research for optimizing various processes including transesterification reaction of vegetable oils: Beniseed oil [4], Moringa oleifera [7], Sorrel oil [8], Jatropha oil [9] and cottonseed oil [10] to mention a few. The main advantage of RSM is the ability to reduce the number of experimental runs needed to arrive at optimized and statistically acceptable results. Thus, it saves time and less difficult compared with full-factorial design [11]. In this present study, an effort was made to optimize the process conditions for the transesterification step of

Chrysophyllum albidium seed oil. Fatty acid composition and physicochemical analysis of the produced biodiesel was also carried out with a view to determine it suitability as renewable fuel. 


\section{METHODOLOGY}

\subsection{Extraction of Chrysophyllum Albidium Seed Oil}

The method employed by Betiku, et al. [4] was used for this study. The seed of Chrysophyllum albidium were collected from Omu-Aran market, Kwara State, Nigeria. The chaffs were winnowed from the oilseeds and the clean seed was sun dried and then milled into powder. 1-liter Soxhlet apparatus and n-hexane as solvent were used for the oil extraction.

\subsection{Experimental Design of Chrysophyllum Albidium Biodiesel Production}

In this study, central composite rotatable design (CCRD) was employed to optimize the Chrysophyllum albidium biodiesel production. Five-level-four factors design was employed, which generated 30 experimental runs. This included 16 factorial points, 8 axial points, and 6 central points to provide information regarding the interior of the experimental region, making it possible to evaluate the curvature effect. Selected factors for transesterification process are reaction time $(\mathrm{min}) ; \mathrm{X}_{1}$, reaction temperature $\left({ }^{\circ} \mathrm{C}\right) ; \mathrm{X}_{2}$, catalyst amount $(\% \mathrm{wt}) ; \mathrm{X}_{3}$, and methanol/oil molar ratio (v/v); $\mathrm{X}_{4}$. The coded levels of the independent factors are given in Table 1. However, the experiments were randomizes to minimize the effects of unexplained variability in the observed response due to extraneous factors.

Table-1. Factors and their levels for composite central rotatable design

\begin{tabular}{lllllll}
\hline Variable & Symbol & \multicolumn{2}{l}{ Coded factor levels } & & \\
\hline & & -2 & -1 & 0 & 1 & 2 \\
\hline Reaction temperature $\left({ }^{\circ} \mathrm{C}\right)$ & $\mathrm{X}_{1}$ & 40 & 45 & 50 & 55 & 60 \\
\hline Catalyst amount $(\mathrm{wt} \%)$ & $\mathrm{X}_{2}$ & 0.5 & 0.6 & 0.7 & 0.8 & 0.9 \\
\hline Reaction time $(\mathrm{min})$ & $\mathrm{X}_{3}$ & 40 & 45 & 50 & 55 & 60 \\
\hline Methanol/oil ratio & $\mathrm{X}_{4}$ & 3 & 4 & 5 & 6 & 7 \\
\hline
\end{tabular}

Source: Response surface methodology (Design-Expert software version 8.0.3.1)

\subsection{Chrysophyllum Albidium Biodiesel Production Procedure}

Alkalis catalyst transesterification reaction was applied for the biodiesel production, due to the low FFA value of the seed oil. A known weight of $\mathrm{NaOH}$ pellet was dissolved in a known volume of anhydrous methanol and was quickly transferred into the Chrysophyllum albidium oil in the reactor placed on the hot plate magnetic stirrer, the reaction was monitored according to the design variables from CCRD. At the reaction completion, the product was transferred to a separating funnel for glycerol and biodiesel separation. Glycerol was tapped off and the biodiesel left in the separating funnel was washed with ionized water to remove residual catalyst, untapped glycerol, methanol and soap. The washed biodiesel was further dried over heated calcium chloride $\left(\mathrm{CaCl}_{2}\right)$ powder. The final biodiesel yield was determined using Eqn. 1

$$
\text { Biodiesel yield } \%(w / w)=\frac{\text { Weight of Chrysophyllum albidium oil used }}{\text { Weight of biodiesel produced }}
$$




\subsection{Statistical Data Analysis}

Chrysophyllum albidium biodiesel production data were analyzed statistically using RSM, so as to fit the quadratic polynomial equation generated by the Design-Expert software version 8.0.3.1 (State-Ease Inc., Minneapolis, USA). To correlate the response variable (Y) to the independent factors, multiple regressions was used to fit the coefficient of the polynomial model. The quality of the fit model was evaluated using test of significance and variance analysis (ANOVA). The fitted quadratic response model is given by Eqn. 2

$Y=b_{0}+\sum_{i=1}^{k} b_{i} X_{i}+\sum_{i=1}^{k} b_{i i} X_{i}^{2}+\sum_{i<j}^{k} b_{i j} X_{i} X_{j}+e$

Where, $Y$ is response factor (Chrysophyllum albidium biodiesel), $b_{o}$ is the intercept value, $b_{i} \mathrm{i}=1$, $2, \mathrm{k})$ is the first order model coefficient, $\mathrm{b}_{\mathrm{ij}}$ is the interaction effect, and $\mathrm{b}_{\mathrm{ii}}$ represents the quadratic coefficients of $\mathrm{X}_{\mathrm{i}}$, and $e$ is the random error.

\subsection{Quality and Fuel Properties of Chrysophyllum albidium Biodiesel}

Fuel properties namely, moisture content, specific gravity, kinematic viscosity at $40{ }^{\circ} \mathrm{C}$, acid value, saponification value, higher heating value, flash point, cloud point and cetane number of Chrysophyllum albidium biodiesel were determined following standard methods and compared with American and European standards (ASTM and DIN EN 14214).

\section{RESULTS AND DISCUSSION}

\subsection{Optimization of the Transesterification Step}

Table 2 depicts the coded factors considered in this study with experimental values, predicted values as well as the residual values obtained. Figure 1 shows the predicted against the actual values. Design Expert 8.0.3.1 software was employed to evaluate and determine the coefficients of the full regression model equation and their statistical significance. Table 3 shows the significance results for every regression coefficient. The results showed that the p-value of the model terms were significant, i.e. $\mathrm{p}<0.05$. In this case, the four linear terms $\left(\mathrm{X}_{1}, \mathrm{X}_{2}, \mathrm{X}_{3}, \mathrm{X}_{4}\right)$, four crossproducts $\left(\mathrm{X}_{1} \mathrm{X}_{3}, \mathrm{X}_{1} \mathrm{X}_{4}, \mathrm{X}_{2} \mathrm{X}_{3}, \mathrm{X}_{3} \mathrm{X}_{4}\right)$ and the four quadratic terms $\left(\mathrm{X}_{1}{ }^{2}, \mathrm{X}_{2}{ }^{2}, \mathrm{X}_{3}{ }^{2}\right.$ and $\left.\mathrm{X}_{4}{ }^{2}\right)$ were all remarkably significant model terms at $95 \%$ confidence level except $\mathrm{X}_{1} \mathrm{X}_{2}$ and $\mathrm{X}_{2} \mathrm{X}_{4}$. However, all other model terms were more significant than $\mathrm{X}_{4}$. In order to minimize error, all the coefficients were considered in the design. Table 4 shows the variance of analysis (ANOVA) of the regression equation. The model F-value of 364.20 implied a high significant for the regression model [12]. The goodness of the fit of a model was checked by the determination coefficient $\left(\mathrm{R}^{2}\right) \cdot \mathrm{R}^{2}$ should be at least 0.80 for the good fit of a model [13]. The $\mathrm{R}^{2}$ of 0.9978 in this case indicated that the sample variation of $99.78 \%$ for Chrysophyllum albidium biodiesel yield was attributed to the independent factors and only $0.32 \%$ of the total variation are not explained by the model. The value of adjusted determination coefficient (Adj. $\left.\mathrm{R}^{2}=0.9958\right)$ was also very high, supporting a 
high significant of the model [14] and all p-value coefficients were less than 0.0001 , which implied that the model proved suitable for the adequate representation of the actual relationship among the selected variables. The lack-of-fit term of 0.9138 was not significant relative to the pure error.

Table-2. Central Composite Design (CCD), Experimental, Predicted and Residual Values for Five - Level-Four Factors Response Surface Analysis

\begin{tabular}{|c|c|c|c|c|c|c|c|}
\hline $\begin{array}{l}\text { Std } \\
\text { order }\end{array}$ & $\begin{array}{l}\mathbf{X}_{1} \\
\left({ }^{\circ} \mathbf{C}\right)\end{array}$ & $\begin{array}{l}\mathrm{X}_{2} \\
\text { (wt \%) }\end{array}$ & $\begin{array}{l}\mathbf{X}_{s} \\
(\min )\end{array}$ & $\mathbf{X}_{4}$ & $\begin{array}{l}\text { Experimental } \\
\text { value } \%(w / w)\end{array}$ & $\begin{array}{l}\text { Predicted value } \\
\%(w / w)\end{array}$ & $\begin{array}{l}\text { Residual values } \\
\%(w / w) \%\end{array}$ \\
\hline 1 & -1 & -1 & -1 & -1 & 79.00 & 79.17 & -0.17 \\
\hline 2 & 1 & -1 & -1 & -1 & 80.00 & 79.75 & 0.2525 \\
\hline 3 & -1 & 1 & -1 & -1 & 83.92 & 83.83 & 0.093 \\
\hline 4 & 1 & 1 & -1 & -1 & 84.79 & 84.88 & -0.090 \\
\hline 5 & -1 & -1 & 1 & -1 & 80.90 & 80.84 & 0.065 \\
\hline 6 & 1 & -1 & 1 & -1 & 80.20 & 80.25 & -0.054 \\
\hline 7 & -1 & 1 & 1 & -1 & 83.70 & 80.62 & 0.081 \\
\hline 8 & 1 & 1 & 1 & -1 & 83.60 & 83.52 & 0.085 \\
\hline 9 & -1 & -1 & -1 & 1 & 77.00 & 76.86 & 0.14 \\
\hline 10 & 1 & -1 & -1 & 1 & 80.70 & 80.81 & -0.11 \\
\hline 11 & -1 & 1 & -1 & 1 & 81.20 & 81.18 & 0.021 \\
\hline 12 & 1 & 1 & -1 & 1 & 85.78 & 85.62 & 0.16 \\
\hline 13 & -1 & -1 & 1 & 1 & 80.73 & 80.67 & 0.058 \\
\hline 14 & 1 & -1 & 1 & 1 & 83.61 & 83.47 & 0.14 \\
\hline 15 & -1 & 1 & 1 & 1 & 83.10 & 83.12 & -0.023 \\
\hline 16 & 1 & 1 & 1 & 1 & 86.54 & 86.40 & 0.14 \\
\hline 17 & -2 & 0 & $\mathrm{O}$ & $\mathrm{O}$ & 80.15 & 80.19 & -0.036 \\
\hline 18 & 2 & 0 & $\mathrm{O}$ & 0 & 83.88 & 84.04 & -0.16 \\
\hline 19 & $\mathrm{O}$ & -2 & 0 & 0 & 79.29 & 79.35 & -0.061 \\
\hline 20 & $\mathrm{O}$ & 2 & $\mathrm{O}$ & 0 & 86.80 & 86.94 & -0.14 \\
\hline 21 & $\mathrm{O}$ & 0 & -2 & $\mathrm{O}$ & 80.64 & 80.69 & -0.053 \\
\hline 22 & $\mathrm{O}$ & 0 & 2 & 0 & 83.00 & 83.14 & -0.14 \\
\hline 23 & $\mathrm{O}$ & 0 & 0 & -2 & 81.00 & 81.03 & -0.033 \\
\hline 24 & $\mathrm{O}$ & 0 & 0 & 2 & 81.44 & 81.60 & -0.61 \\
\hline 25 & $\mathrm{O}$ & 0 & $\mathrm{O}$ & $\mathrm{O}$ & 88.50 & 88.92 & -0.42 \\
\hline 26 & $\mathrm{O}$ & 0 & 0 & 0 & 89.30 & 88.92 & 0.38 \\
\hline 27 & $\mathrm{O}$ & 0 & 0 & 0 & 89.10 & 88.92 & 0.18 \\
\hline 28 & $\mathrm{O}$ & 0 & 0 & 0 & 88.65 & 88.92 & -0.27 \\
\hline 29 & 0 & 0 & 0 & 0 & 89.07 & 88.92 & 0.15 \\
\hline 30 & 0 & 0 & 0 & 0 & 88.87 & 88.92 & -0.045 \\
\hline
\end{tabular}

Source: Response surface methodology-CCD- (Design-Expert software version 8.0.3.1)

Figure-1. Plot of predicted yield against the experimental yield

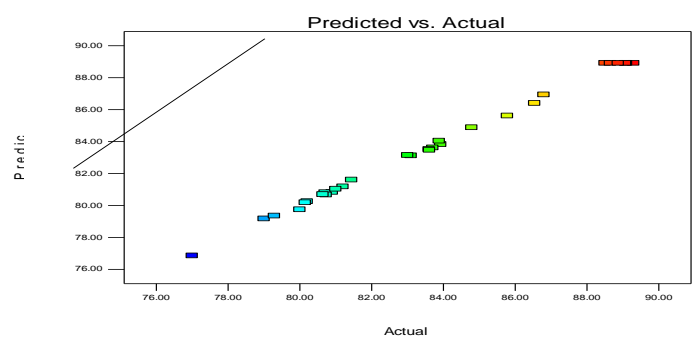

Source: Design-Expert software version 8.0.3.1 
International Journal of Chemical and Process Engineering Research, 2014, 1(4): 32-42

Table-3. Test of Significance for Every Regression Coefficient of CCD

\begin{tabular}{lllllr}
\hline Source & Sum of Squares & $\mathrm{df}$ & Mean Square & F-Value & $\mathrm{p}$-value \\
\hline $\mathrm{X}_{1}$ & 22.90 & 1 & 22.90 & 425.01 & $<0.0001$ \\
\hline $\mathrm{X}_{2}$ & 86.30 & 1 & 86.30 & 1645.36 & $<0.0001$ \\
\hline $\mathrm{X}_{3}$ & 9.02 & 1 & 9.02 & 171.90 & $<0.0001$ \\
\hline $\mathrm{X}_{4}$ & 0.49 & 1 & 0.49 & 9.35 & 0.0080 \\
\hline $\mathrm{X}_{1} \mathrm{X}_{2}$ & 0.23 & 1 & 0.23 & 4.35 & 0.0546 \\
\hline $\mathrm{X}_{1} \mathrm{X}_{3}$ & 1.34 & 1 & 1.34 & 25.54 & $<0.0001$ \\
\hline $\mathrm{X}_{1} \mathrm{X}_{4}$ & 11.44 & 1 & 11.44 & 218.14 & $<0.0001$ \\
\hline $\mathrm{X}_{2} \mathrm{X}_{3}$ & 3.51 & 1 & 3.51 & 66.85 & $<0.0001$ \\
\hline $\mathrm{X}_{2} \mathrm{X}_{4}$ & 0.11 & 1 & 0.11 & 2.11 & 0.1671 \\
\hline $\mathrm{X}_{3} \mathrm{X}_{4}$ & 4.63 & 1 & 4.63 & 88.34 & $<0.0001$ \\
\hline $\mathrm{X}_{1}{ }^{2}$ & 79.30 & 1 & 79.30 & 1511.89 & $<0.0001$ \\
\hline $\mathrm{X}_{2}{ }^{2}$ & 57.10 & 1 & 57.10 & 1088.63 & $<0.0001$ \\
\hline $\mathrm{X}_{3}{ }^{2}$ & 83.91 & 1 & 83.91 & 1599.83 & $<0.0001$ \\
\hline $\mathrm{X}_{4}{ }^{2}$ & 98.92 & 1 & 98.92 & 1886.00 & $<0.0001$ \\
\hline
\end{tabular}

Source: Response surface methodology-CCD- (Design-Expert software version 8.0.3.1)

Table-4. Analysis of Variance (ANOVA) of Regression Equation

\begin{tabular}{llllll}
\hline Source & $\begin{array}{l}\text { Sum of } \\
\text { squares }\end{array}$ & df & $\begin{array}{l}\text { Mean } \\
\text { Square }\end{array}$ & F-value & p-value \\
\hline Model & 364.20 & 14 & 26.01 & 495.98 & $<0.0001$ \\
\hline Residual & 0.79 & 15 & 0.052 & & \\
\hline Lack of Fit & 0.34 & 10 & 0.084 & 0.37 & \\
\hline Pure Error & 0.45 & 5 & 0.090 & & \\
\hline Cor Total & 364.98 & 29 & & R-Sq $=99.78 \%$, & R-Sq(adj) $=99.58 \%$ \\
\hline
\end{tabular}

Source: Response surface methodology-CCD- (Design-Expert software version 8.0.3.1)

Table-5. ANOVA for Response Surface Quadratic Model for Intercept.

\begin{tabular}{lllllll}
\hline Factors & $\begin{array}{l}\text { Coefficient } \\
\text { Estimate }\end{array}$ & $\mathbf{d f}$ & $\begin{array}{l}\text { Standard } \\
\text { Error }\end{array}$ & $\begin{array}{l}\mathbf{9 5 \% C I} \\
\text { Low }\end{array}$ & $\begin{array}{l}\mathbf{9 5 \% C I} \\
\text { High }\end{array}$ & VIF \\
\hline Intercept & 88.92 & 1 & 0.093 & 88.72 & 89.11 & - \\
\hline $\mathrm{X}_{1}$ & 0.96 & 1 & 0.047 & 0.86 & 1.06 & 1.00 \\
\hline $\mathrm{X}_{2}$ & 1.90 & 1 & 0.047 & 1.80 & 2.00 & 1.00 \\
\hline $\mathrm{X}_{3}$ & 0.61 & 1 & 0.047 & 0.51 & 0.71 & 1.00 \\
\hline $\mathrm{X}_{4}$ & 0.14 & 1 & 0.047 & 0.043 & 0.24 & 1.00 \\
\hline $\mathrm{X}_{1} \mathrm{X}_{2}$ & 0.12 & 1 & 0.057 & -0.00266 & 0.24 & 1.00 \\
\hline $\mathrm{X}_{1} \mathrm{X}_{3}$ & -0.29 & 1 & 0.057 & -0.41 & -0.17 & 1.00 \\
\hline $\mathrm{X}_{1} \mathrm{X}_{4}$ & 0.85 & 1 & 0.057 & 0.72 & 0.97 & 1.00 \\
\hline $\mathrm{X}_{2} \mathrm{X}_{3}$ & -0.47 & 1 & 0.057 & -0.59 & -0.35 & 1.00 \\
\hline $\mathrm{X}_{2} \mathrm{X}_{4}$ & -0.083 & 1 & 0.057 & -0.21 & 0.039 & 1.00 \\
\hline $\mathrm{X}_{3} \mathrm{X}_{4}$ & 0.54 & 1 & 0.057 & 0.42 & 0.66 & 1.00 \\
\hline $\mathrm{X}_{1}{ }^{2}$ & -1.70 & 1 & 0.044 & -1.79 & -1.61 & 1.05 \\
\hline $\mathrm{X}_{2}{ }^{2}$ & -1.44 & 1 & 0.044 & -1.54 & -1.35 & 1.05 \\
\hline $\mathrm{X}_{3}{ }^{2}$ & -1.75 & 1 & 0.044 & -1.84 & -1.66 & 1.05 \\
\hline $\mathrm{X}_{4}{ }^{2}$ & -1.90 & 1 & 0.044 & -1.99 & -1.81 & 1.05 \\
\hline
\end{tabular}

Source: Response surface methodology-CCD- (Design-Expert software version 8.0.3.1) 
The final equation in terms of coded factors for the response surface quadratic model is expressed in Eqn. (3).

$$
\begin{aligned}
& Y(w / w \%)=88.92+0.96 X_{1}+1.90 X_{2}+0.61 X_{3}+0.14 X_{4}+0.12 X_{1} X_{2}-0.29 X_{1} X_{3}+ \\
& 0.85 X_{1} X_{4}-0.457 X_{3}-0.083 X_{2} X_{4}+0.54 X_{3} X_{4}-1.70 X_{1}^{2}-1.44 X_{2}^{2}-1.75 X_{3}^{2}-1.90 X_{4}^{2}
\end{aligned}
$$

All the $\mathrm{X}_{1}, \mathrm{X}_{2}, \mathrm{X}_{3}, \mathrm{X}_{4}, \mathrm{X}_{1} \mathrm{X}_{2}, \mathrm{X}_{1} \mathrm{X}_{4}$ and $\mathrm{X}_{3} \mathrm{X}_{4}$ had positive effect on the Chrysophyllum albidium biodiesel yield while the rest had negative influence on the yield (Table 4).

In general, the contour and $3 \mathrm{D}$ response surface plot is a graphical representation of the regression equation for the optimization of the reaction variables. Figure $2(\mathrm{a}-\mathrm{f})$ described the contours and 3D surfaces linked to the effect of two variables on the yield of Chrysophyllum albidium biodiesel. The curvatures nature of $3 \mathrm{D}$ surfaces in Fig. 2b, c, e and findicated the mutual interaction of the reaction time with reaction temperature, methanol/oil molar ratio with reaction temperature, methanol/oil molar ratio with catalyst amount and methanol/oil molar ratio

Figure-2. Contour and $3 \mathrm{D}$ response surface plots

(a)
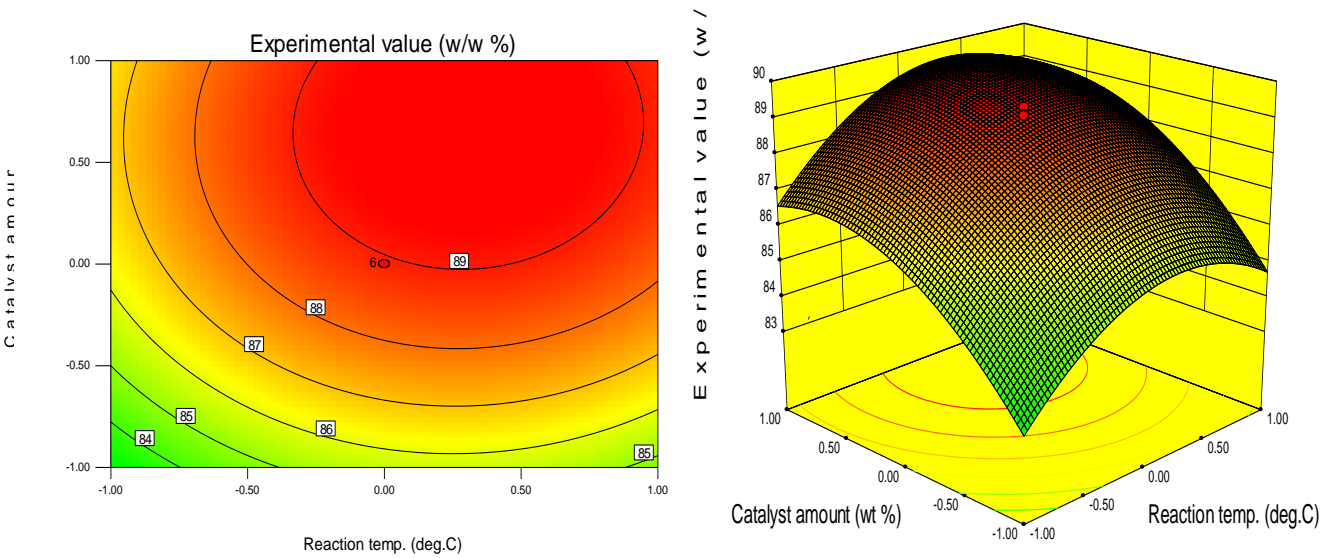

(b)

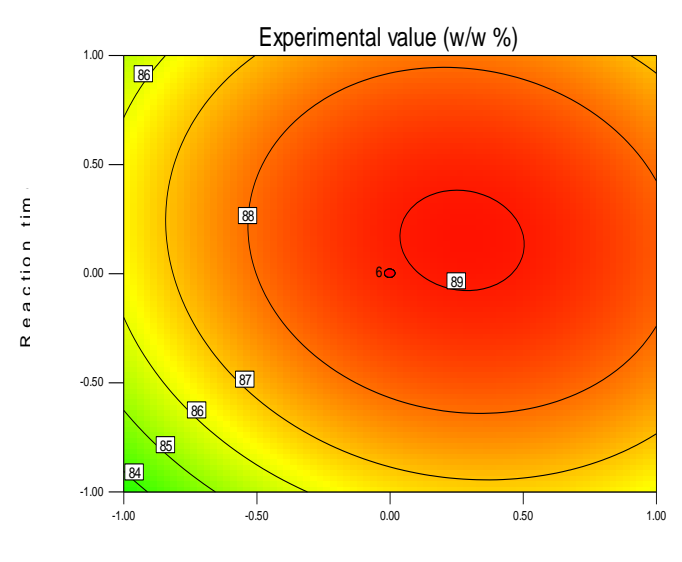

Reaction temp. (deg.C)

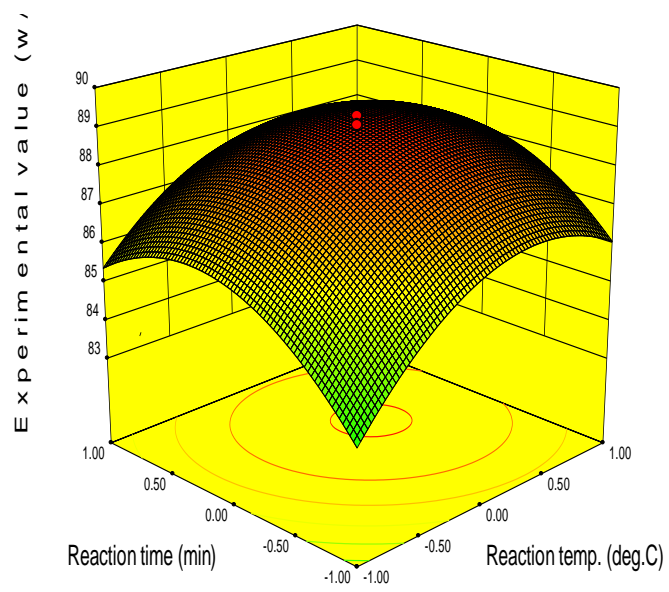


International Journal of Chemical and Process Engineering Research, 2014, 1(4): 32-42

(c)
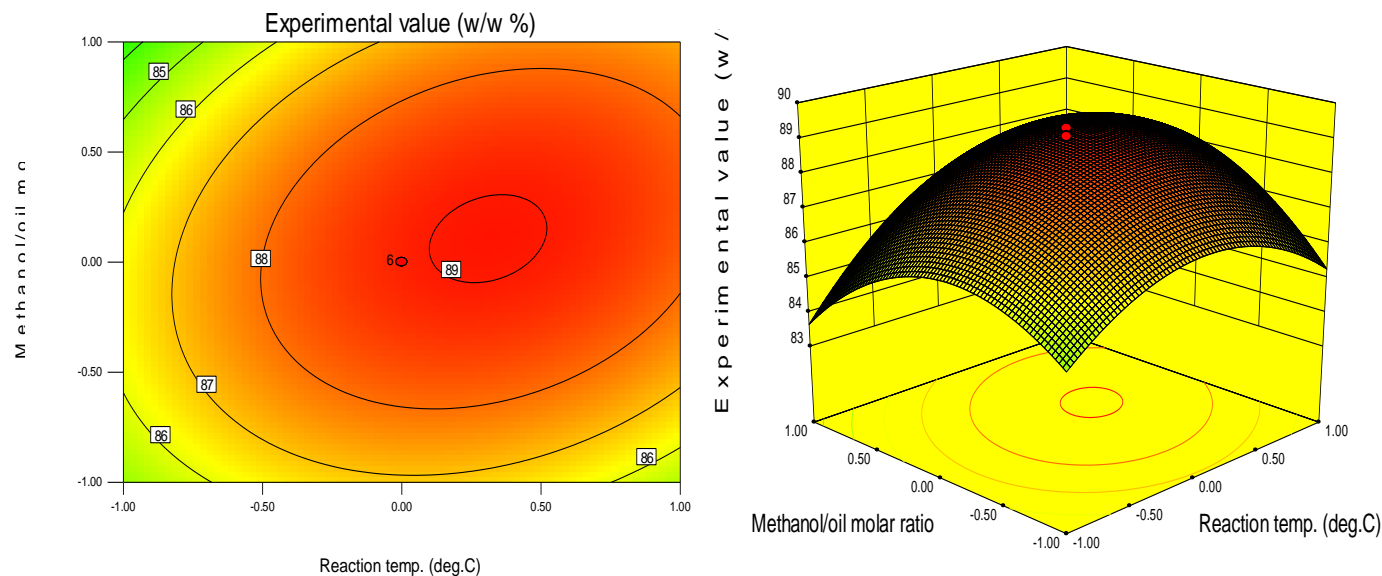

(d)
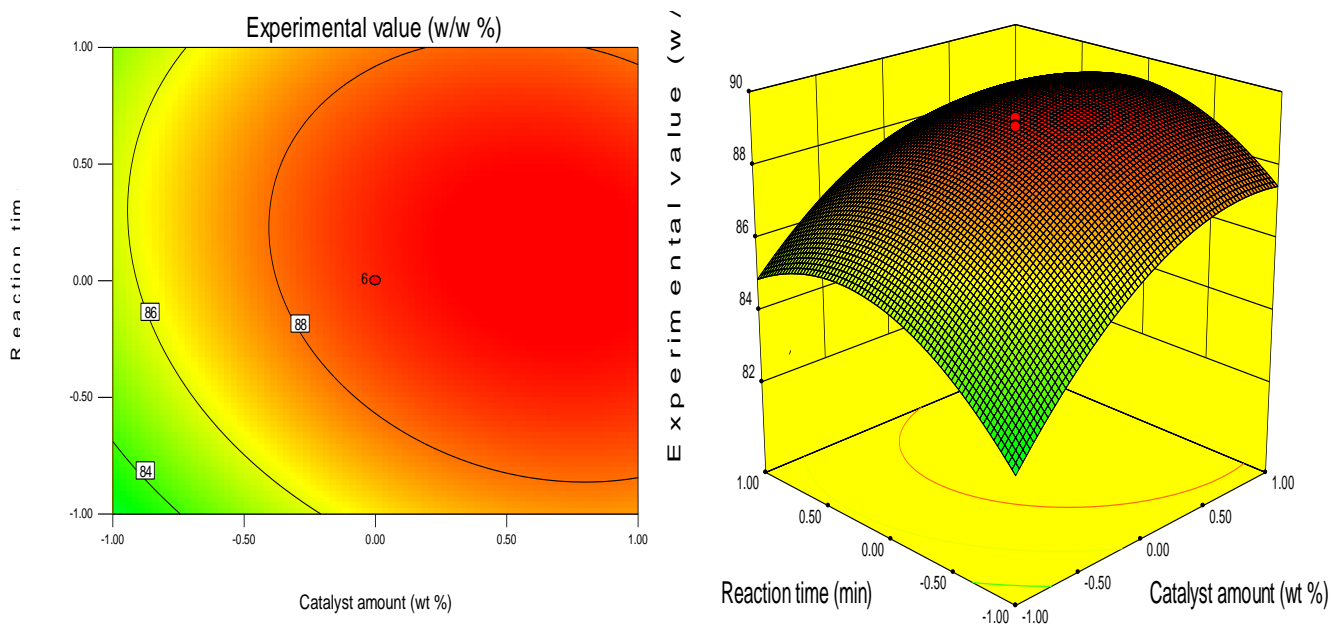

(e)
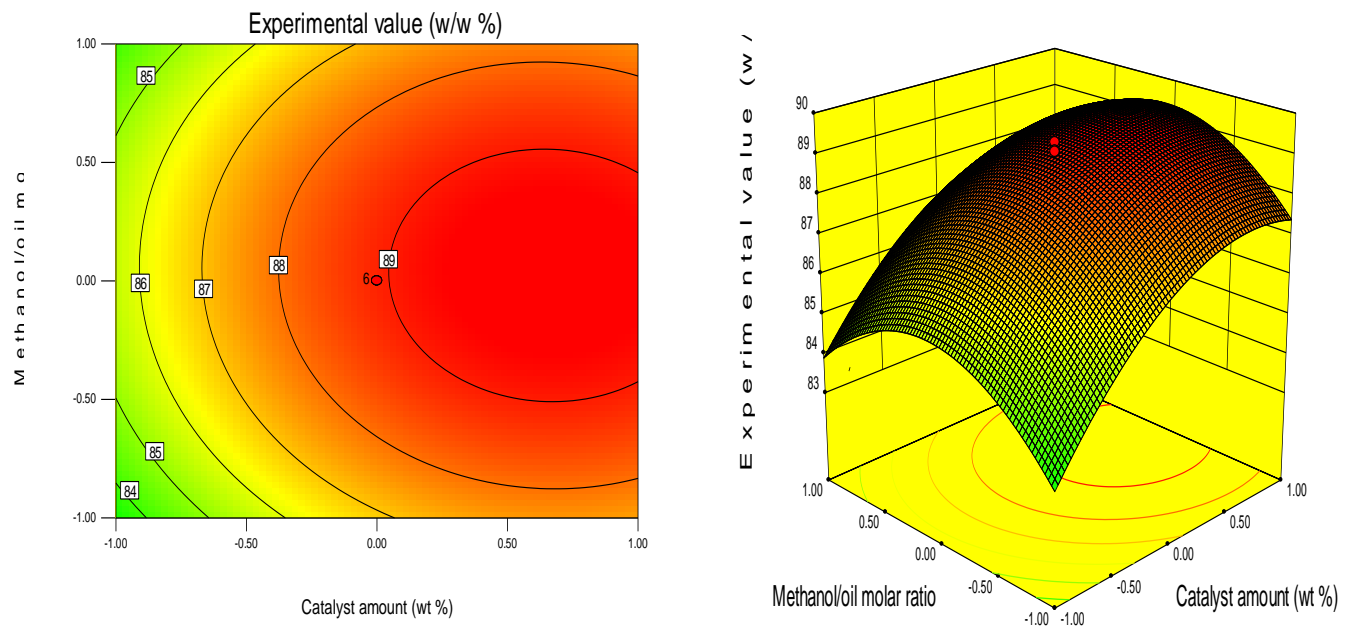
(f)
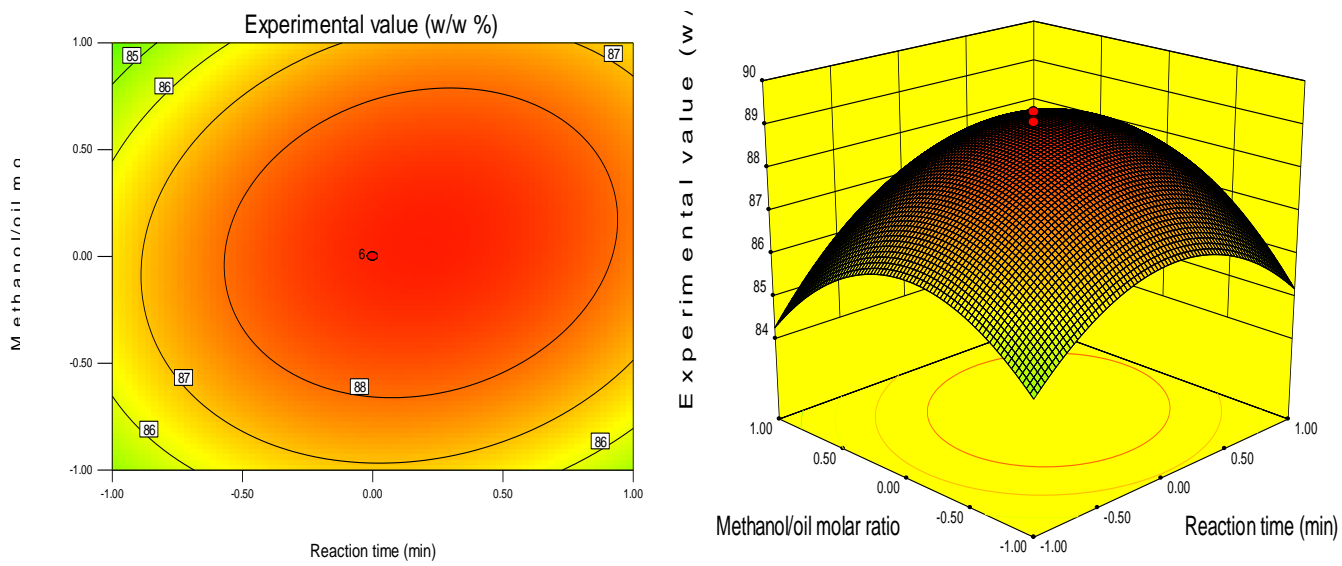

with reaction time, respectively. Meanwhile, there was a moderate interaction examined between catalyst amount with reaction temperature (Fig. 2a), but no interaction was observed between reaction time and catalyst amount as represented in Fig.2d. The optimal condition predicted by the model were reaction temperature of $41.63{ }^{\circ} \mathrm{C}$, catalyst amount of 0.59 (\%wt.), reaction time of $62.32 \mathrm{~min}$ and methanol/oil molar ratio of 6.21 which gave $82.7323 \%(\mathrm{w} / \mathrm{w})$. Using these optimal condition values for three independent experimental replicates, an average Chrysophyllum albidium biodiesel yield of $82.6702 \%(\mathrm{w} / \mathrm{w})$ was achieved, which was well within the range predicted by the model.

Table-6. Properties of Chrysophyllum albidium biodiesel in Comparison with Biodiesel Standards

\begin{tabular}{llll}
\hline Parameters & $\begin{array}{l}\text { Chrysophyllum } \\
\text { albidium } \\
\text { biodiesel }\end{array}$ & $\begin{array}{l}\text { ASTM } \\
\text { D6751 }\end{array}$ & $\begin{array}{l}\text { DIN EN } \\
\mathbf{1 4 2 1 4}\end{array}$ \\
\hline Moisture content \% & $<<<1 \mathrm{ppm}$ & $<0.03$ & 0.02 \\
\hline Specific gravity $@ 40{ }^{\circ} \mathrm{C}$ & 0.846 & $0.86-0.90$ & 0.85 \\
\hline Viscosity at $40{ }^{\circ} \mathrm{C}\left(\mathrm{mm}^{2} / \mathrm{s}\right)$ & 4.00 & $1.9-6.0$ & $3.5-5.0$ \\
\hline Iodine Value $\left(\mathrm{g} \mathrm{I}_{2} / 100 \mathrm{~g}\right)$ & 68.50 & - & 120 max \\
\hline Acid Value & 0.54 & $<0.80$ & 0.5 max \\
\hline Saponification value $(\mathrm{mg} \mathrm{KOH} / \mathrm{g}$ oil $)$ & 215.40 & - & - \\
\hline Higher heating value $(\mathrm{MJ} / \mathrm{kg})$ & 39.57 & - & - \\
\hline Diesel index & 66.04 & 50.40 min & - \\
\hline API & 45.38 & 36.95 & - \\
\hline Cetane number & 56.23 & 47 min & 51 min \\
\hline Aniline point & 145.53 & 331.00 & - \\
\hline Pour Point ${ }^{\circ} \mathrm{C}$ & -18 & Not specific & Not specific. \\
\hline Cloud Point ${ }^{\circ} \mathrm{C}$ & +6 & Report & Not specific. \\
\hline Flash Point ${ }^{\circ} \mathrm{C}$ & 158 & 93 min & 120 min \\
\hline
\end{tabular}

Source: ASTM D6751 and DIN EN 14214 Biodiesel Standard 


\subsection{Quality and Fuel Properties of Chrysophyllum Albidium Biodiesel}

Table 6 shows the Chrysophyllum albidium biodiesel properties in comparison with ASTM biodiesel and DIN EN 14214 standards. All the tested characteristics and fuel properties of the Chrysophyllum albidium biodiesel satisfied both the ASTM D 6751 and DIN EN 1424 standards. Gas chromatography analysis of fatty acids present in the Chrysophyllum albidium biodiesel is shown in Table 7. The results indicated Chrysophyllum albidium biodiesel was highly unsaturated with dominant fatty acids such as oleic $(60.101 \%)$, arachidic $(2.0145 \%)$, palmitic $(18.403 \%)$ and linoleic $(18.942 \%)$.

Table-7. Fatty Acids Compositions of the Chrysophyllum albidium biodiesel Produced

\begin{tabular}{ll}
\hline Fatty acid & Compositions \% \\
\hline Palmitic acid (C16:0) & 18.403 \\
\hline Palmitoleic acids (C16:1) & 0.045 \\
\hline Stearic acids (C18:0) & 0.323 \\
\hline Oleic acids (C18:1) & 60.101 \\
\hline Linoleic acids (C18:2) & 18.942 \\
\hline Linolenic acid (C18:3) & 0.065 \\
\hline Myristic acid (C14:0) & 0.055 \\
\hline Arachidonic acid (C20:4) & 2.045 \\
\hline Other & 0.021 \\
\hline Total & 100 \\
\hline
\end{tabular}

Source: Gas chromatography analysis

\section{CONCLUSIONS}

In this study, experiments were conducted using RSM to determine the effects of four reaction factors namely reaction temperature, reaction time, catalyst concentration and methanol/oil molar ratio on Chrysophyllum albidium biodiesel yield in the transesterification of the Chrysophyllum albidium seed oil. The maximum Chrysophyllum albidium biodiesel conversion yield was validated to be $82.6702 \%(\mathrm{w} / \mathrm{w})$ at the reaction temperature of $62.32{ }^{\circ} \mathrm{C}$, a catalyst amount of 0.59 wt. \%, methanol/oil molar ratio of 3 and reaction time of $51 \mathrm{~min}$. The fuel properties of the Chrysophyllum albidium biodiesel were within the ASTM D6751 and DIN EN 14214 specifications.

\section{ACKNOWLEDGEMENTS}

Adepoju, T. F. appreciatively acknowledged the effort of technical staff of Landmark University, Omu-Aran, Kwara State, Nigeria.

\section{REFERENCES}

[1] T. F. Adepoju and O. Olamide, "Acid-catalyzed esterification of waste cooking oil (WCO) with high FFA for biodiesel production," Chemical and Process Engineering Research, vol. 21, pp. 80-85, 2014. 
[2] G. Knothe, J. Krahl, and J. V. Gerpen, The biodiesel handbook. Champaign, IL: AOCS Press, 2007.

[3] A. Shote, E. Betiku, and A. A. Asere, "Biodiesel production by transmethylation of Nigeria palm kernel oil," Ife Journal of Technology, vol. 18, pp. 1-4, 2009.

[4] E. Betiku, T. F. Adepoju, and B. O. Solomon, "Statistical approach to alcoholysis optimization of sorrel (Hibiscus Sabdariffa) seed oil to biodiesel and emission assessment of its blends," IFE Journal of Technology, vol. 2, pp. 20-24, 2012a.

[5] K. Ajewole and A. Adeyeye, "Seed oil of white star apple (Chrysophyllum Albidum)physicochemical characteristics and fatty acid composition," Journal of the Science of Food and Agriculture, vol. 54, pp. 313-315, 1991.

[6] O. C. Ugboge and A. R. Akukwe, "The antimicrobial effect of oil from pentaclethra macrophyll bent, chrysophyllum albidum G. don and persea gratissima gaerth $\mathrm{F}$ on some local clinical bacteria isolates," African Journal of Biotechnology, vol. 8, pp. 285, 2009.

[7] U. Rashid, F. Anwar, M. Ashraf, M. Saleem, and S. Yusup, "Application of response surface methodology for optimizing transesterification of moringa oleifera oil: Biodiesel production," Energ. Convers. Manage, vol. 52, pp. 3034-3042, 2011.

[8] E. Betiku, T. F. Adepoju, K. O. Akinbiyi, and S. E. Aluko, "Statistical approach to the optimization of oil from beniseed (Sesamum Indicum) oilseeds," Journal of Food Science and Engineering, vol. 2, pp. 351-357, $2012 \mathrm{~b}$.

[9] A. K. Tiwari, A. Kumar, and H. Raheman, "Biodiesel production from jatropha oil (Jatropha Curcas) with high free fatty acids: An optimized process," Biomass Bioenerg, vol. 31, pp. 569-575, 2007.

[10] X. W. Zhang and W. Huang, "Optimization of the transesterification reaction from cottenseed oil using a statistical approach," Energ. Sources, vol. 33, pp. 1107-1116, 2011.

[11] C. H. Tan, H. M. Ghazali, A. Kuntom, C. P. Tan, and A. A. Ariffin, "Extraction and physicochemical properties of low free fatty acid crude palm oil," Food Chemistry, vol. 113, pp. 645$650,2009$.

[12] X. Yuan, J. Liu, G. Zeng, J. Shi, J. Tong, and G. Huang, "Optimization of conversion of waste rapeseed oil with high FFA to biodiesel using response surface methodology," Renewable Energy, vol. 33, pp. 1678-1684, 2008.

[13] X. Guan and H. Yao, "Optimization of viscozyme L-assisted extraction of oat bran protein using response surface methodology," Food Chemistry, vol. 106, pp. 345-351, 2008.

[14] A. I. Khuri and J. A. Cornell, Response surfaces: Design and analysis. New York: Marcel Dekker, 1987. 